See discussions, stats, and author profiles for this publication at: https://www.researchgate.net/publication/340974543

\title{
Examining employees' behavioural outcomes within the context of organisational justice
}

Article in Contemporary Social Science: Journal of the Academy of Social Sciences · April 2020 DOI: 10.1080/21582041.2020.1733646

CITATION

6 authors, including:

Dayo Idowu Akintayo

Osun State University

26 PUBLICATIONS 195 CITATIONS

SEE PROFILE

David Imhonopi

Covenant University Ota Ogun State, Nigeria

62 PUBLICATIONS 298 CITATIONS

SEE PROFILE

Some of the authors of this publication are also working on these related projects:

A Published Research Article View project

Corporate governance and behaviour View project

\section{READ}

45

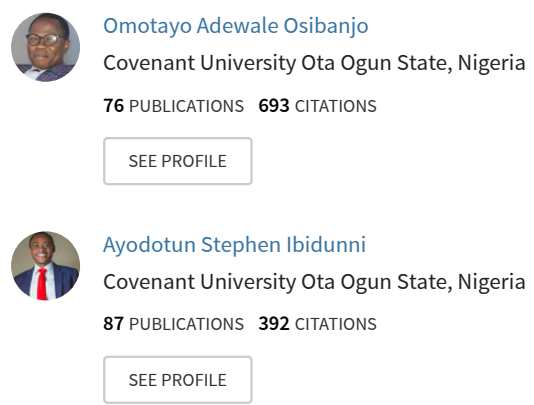


Journal

\section{Contemporary Social Science >}

Journal of the Academy of Social Sciences

Latest Articles

200

Views CrossRef citations to date Altmetric

Articles

\section{Examining employees' behavioural outcomes within the context of organisational justice}

Young Waribo, Dayo I. Akintayo, Adewale Omotayo Osibanjo, David Imhonopi, Ayodotun Stephen Ibidunni $\boldsymbol{\nabla}$ \& Olatunji Idowu Fadeyi

Received 23 Jan 2019, Accepted 17 Feb 2020, Published online: 27 Apr 2020

S6 Download citation $\boldsymbol{D}$ https://doi.org/10.1080/21582041.2020.1733646

D) Check for updates

Select Language $\mid \boldsymbol{\nabla}$

Translator disclaimer

\section{ABSTRACT}

This study was designed to investigate the combined influence of organisational justice on employees' behavioural outcomes. The descriptive survey research design was used for this study. A sample size of 423 respondents was proportionately selected from employees of the six Seaports in Nigeria, administered by Nigeria Ports Authority. Multiple regression was used to analyse the data collected and to test for the effects among the variables. Based on the results, the study concluded that organisational justice (distributive, procedural, interpersonal and informational as well as spatial) has a combined positive

influence on employees' behavioural outcomes. Additionally, this study found that the proactive implementation of the aforementioned dimensions of organisational 
justice (distributive, procedural, informational, interpersonal and spatial) will help organisations ward off some contemporary worrisome employees' behavioural tendencies such as presentism, absenteeism and cynicism with their negative consequences, which include huge financial and material loss as well as extinction. Consequently, the study recommends that organisations should have functional organisational justice policy framework that encompasses all the six dimensions of organisational justice as they have significant influence on employees' behavioural outcomes.

KEYWORDS: Organisational justice, employee behavioural outcomes, procedural justice, distributive justice, employee behaviour, workplace ethics

\section{Login options}

$>\log$ in

$>$ Shibboleth

$>$ OpenAthens

\section{Restore content access}

$>$ Restore content access for purchases made as guest

Purchase *

Save for later

\section{Online}

Article Purchase

24 hours to view or download: USD 44.00

?. Add to cart

Issue Purchase

30 days to view or download: USD 267.00

? Add to cart 
* Local tax will be added as applicable

\section{Additional information}

\section{Disclosure statement}

No potential conflict of interest was reported by the author(s).

\section{Notes on contributors}

Young Waribo hails from Rivers State, Nigeria and holds a PhD in Industrial Relations and Human Resource Management. He has successfully served in various capacities in the real estate and hospitality sectors as well as in the academia. Young is married with two children and is currently a Human Resource and Industrial Relations Consultant.

Professor Dayo I. Akintayo, born in Odeomu, Nigeria, is a Professor of Human Resource Management and Industrial Relations. He has published over seventy articles and attended over thirty conferences across the globe. Professor Akintayo, Idowu Dayo is currently the Provost, College of Management and Social Sciences, Osun State University. He is married with children.

Adewale Omotayo Osibanjo, Lecturer in the Department of Business Management, Covenant University, Ota, Ogun State, Nigeria. He obtained a Doctorate degree of Philosophy in Management at Babes Bolyai University, Cluj-Napoca, Romania under the scholarship of the Romanian Government in the year 2008.

Dr David Imhonopi is Associate professor of Industrial Sociology and he teaches in the department of Sociology, Covenant Unversity, Ota Ogun state. His research interest includes; Industrial Relations, Organisations, Health and development.

Ayodotun Stephen Ibidunni holds a PhD degree in Business Administration. His area of research interest include Strategic Management, Operations Management and Entrepreneurship.

Olatunji Idowu Fadeyi is a PhD holder in Business Administration with specialization in Strategic Management. His work experience span over 16 years in Banking, Entrepreneurship and Academics. Currently he is lecturer at Anchor University Lagos. 
Sample Our

Social Sciences journals

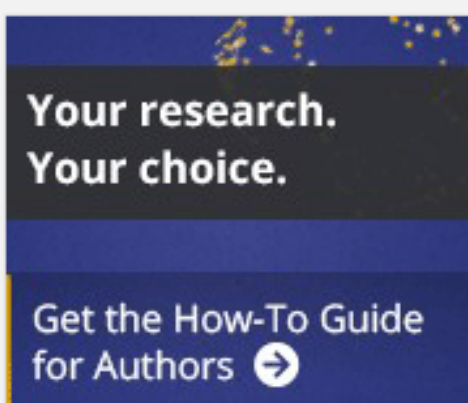

\subsection{M. \\ You do the research \\ We format the text}

Format-free submission.

Click here for more info $\boldsymbol{\Theta}$ 
Information for

Authors

Editors

Librarians

Societies

Help and info

Help \& contact

Newsroom

Commercial services

All journals

Books
Open access

Overview

Open journals

Open Select

Cogent OA

Keep up to date

Register to receive personalised research and resources by email

$\triangle$ Sign me up

$f y$ in

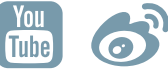

Copyright (c) 2020 Informa UK Limited Privacy policy Cookies Terms \& conditions Accessibility

Registered in England \& Wales No. 3099067

5 Howick Place | London | SW1P 1WG 